\title{
Thyroid Hormone Metabolism in Amniotic and Allantoic Fluids of the Sheep
}

\author{
JOSEPH SACK, DELBERT A. FISHER, (27) AND ROBERT W. LAM \\ Department of Pediatrics, UCLA School of Medicine, Harbor General Hospital, Torrance, California, USA
}

\section{Extract}

Amniotic and allantoic fluid samples were obtained at the time of uterotomy from healthy pregnant ewes at various times during gestation. In most instances maternal and fetal blood was collected simultaneously. Serum thyroxine $\left(\mathrm{T}_{4}\right)$ and triiodithyronine $\left(\mathrm{T}_{3}\right)$ and free $T_{4}$ were measured in most samples. To determine whether conjugates of $T_{4}$ were present in amniotic and allantoic fluids, $T_{4}$ was measured before and after $24-\mathrm{hr}$ acid hydrolysis. $\mathrm{T}_{4}$ and $\mathrm{T}_{3}$ turnover from amniotic fluid were measured using kinetic methods after intravenous or intraamniotic fluid injection of radiolabeled hormones.

$T_{3}$ was unmeasurable ( $\left.<15 \mathrm{ng} / 100 \mathrm{ml}\right)$ in amniotic and allantoic fluids as well as in most fetal serum samples. $T_{4}$ levels in amniotic fluid were low before 120 days of gestation $(0.17 \pm 0.03 \mu \mathrm{g} / 100$ $\mathrm{ml}$; mean and SEM) and increased progressively thereafter to term. The mean (and SEM) concentration between 124 and 152 days was $0.33 \pm 0.03 \mu \mathrm{g} / 100 \mathrm{ml}$. $\mathrm{T}_{4}$ concentrations in allantoic fluid were relatively high before 120 days $(0.57 \pm 0.1 \mu \mathrm{g} / 100 \mathrm{ml}$ and did not increase with progression of the pregnancy. There were no correlations between amniotic and allantoic fluid $T_{4}$ concentrations, between amniotic fluid $\mathrm{T}_{4}$, and either maternal or fetal serum $T_{4}$ levels, or between allantoic fluid $T_{4}$ and maternal or fetal serum $T_{4}$ at any time during gestation. Mean free $T_{4}$ concentrations were similar in fetal serum and amniotic fluid and higher than values in maternal serum or allantoic fluid.

Mean amniotic and allantoic fluid $\mathrm{T}_{4}$ concentrations by radioimmunoassay (RIA) increased significantly after acid hydrolysis, suggesting that one-third to one-half the $T_{4}$ in these fluids is present as $T_{4}$ conjugate.

Radiolabeled $T_{4}$ or $T_{3}$ was injected into amniotic fluid and recovery of hormone label was measured in serum and tissues at 24 $\mathrm{hr}$ for comparison with recoveries after intravenous injection. Mean $\mathrm{T}_{4}$ radioactivity in several organs or tissues was nearly identical whether the hormone was injected intravenously or into amniotic fluid. In addition, the total residual labeled $\mathrm{T}_{4}$ or $\mathrm{T}_{3}$ in the fetal sheep (percentage dose per fetus) at the time of killing was similar after intravenous and intra-amniotic fluid injection. Chromatograms of butanol-ammonia extracts of fetal sera after intraamniotic or intravenous injection of labeled $T_{4}$ were similar and showed predominantly $\mathrm{T}_{4}$; a significant iodide peak was observed as well as a small peak of radioactivity with an $R_{\mathrm{F}}$ corresponding to that of $T_{4}$ conjugate.

The results indicate that there are low but measurable concentrations of $T_{4}$ in amniotic and allantoic fluids of pregnant sheep. There appears to be minimal exchange of hormone between allantoic and amniotic fluid. Amniotic fluid $\mathrm{T}_{4}$ levels, in contrast to allantoic fluid concentrations, increase progressively during the last half of gestation. Although free $T_{4}$ concentrations are similar in amniotic fluid and in fetal serum, and are higher than in allantoic fluid or maternal serum, the lack of correlation between $T_{4}$ levels in either fluid and $T_{4}$ levels in fetal or maternal serum suggests that amniotic or allantoic fluid $T_{4}$ levels do not reliably reflect thyroid status of the fetus or the mother. Rather, both must be represented in some way. Finally, $T_{4}$ and $T_{3}$ appear to be rapidly and quantitatively absorbed from amniotic fluid by the sheep fetus.

\section{Speculation}

The present results suggest that amniotic fluid $T_{4}$ is derived both from the mother and the fetus so that measurement of amniotic fluid $\mathrm{T}_{4}$ would not seem to be a reliable approach to intrauterine diagnesis of fetal thyroid status. Amniotic fluid $\mathrm{T}_{4}$ is turned over rapidly by the fetus, presumably via swallowing and absorption from the fetal gut so that the fetus might acquire maternal thyroid hormones via amniotic fluid even though placental transfer of thyroid hormones is minimal. This route of maternal $\mathrm{T}_{4}$ entry to the fetus must be of minimal quantitative significance, however, since the serum $\mathrm{T}_{4}$ concentration in the athyroid sheep fetus is very low. It should be possible, however, to provide thyroid hormone therapy to the fetus via amniotic fluid injection; this approach allows direct intrauterine therapy of fetuses in whom there is a high index of suspicion of hypothyroidism.

It is now clear that the placenta is essentially impermeable to thyroid hormones, so that treatment of the athyroid fetus is not possible by administration of reasonable doses of thyroxine $\left(\mathrm{T}_{4}\right)$ or triiodothyronine $\left(\mathrm{T}_{3}\right)$ to the pregnant mother $(2,4-9,11-13,15$, $16,18,24)$. However, since it is known that the fetus swallows and absorbs large quantities of amniotic fluid $(1,17)$, it is possible that diagnosis and treatment of the athyroid fetus might be accomplished via amniocentesis. To investigate this possibility we have conducted studies of thyroxine metabolism in amniotic and allantoic fluid of pregnant sheep.

\section{MATERIALS AND METHODS}

Amniotic and allantoic fluid samples were obtained at the time of uterotomy from healthy pregnant ewes (Columbia Suffolk cross), maintained on baled alfalfa. Thirty-five amniotic fluid samples and 36 allantoic fluid samples were obtained from datebred ewes at various periods of gestation. All were obtained at the time of uterotomy at various gestational ages. In many instances maternal and fetal blood samples were collected simultaneously. Amniotic and allantoic fluid samples were immediately frozen and maintained at $-20^{\circ}$ for later study.

Serum amniotic and allantoic fluid $T_{4}$ and $T_{3}$ concentrations were measured by RIA methods using 8-anilino napthalene sulfonic acid (ANS) to block protein binding of $\mathrm{T}_{4}(3)$. Four hundredmilliliter samples of amniotic or allantoic fluid were used with 300 $\mu \mathrm{g}$ ANS/tube as described for human amniotic fluid (20). For the standard curves of the allantoic and amniotic fluid assays, $\mathrm{T}_{4}$ and $\mathrm{T}_{3}$ free fluid was prepared as described by Larsen (14) for human serum. Recovery of $T_{4}$ added to $T_{4}$ free amniotic fluid ranged from 96 to $102 \%$. Free $T_{4}$ in sera and in amniotic and allantoic fluids was estimated using the dialysis and magnesium precipitation method of Sterling and Brenner (23). 
To determine whether conjugates of $\mathrm{T}_{4}$ were present in allantoic and amniotic fluids, 10 paired samples, collected at various gestational ages, were analyzed before and after acid hydrolysis. Samples were hydrolyzed by adding $75 \mu \mathrm{l}$ I N HCl to I ml fluid and incubating at room temperature for $48 \mathrm{hr}$. The incubates then were neutralized by adding $25 \mu \mathrm{l} 3 \mathrm{~N} \mathrm{NaOH}$. Control samples were left at room temperature for $48 \mathrm{hr}$, after which $75 \mu 11 \mathrm{~N} \mathrm{HCl}$ and $25 \mu 13 \mathrm{~N} \mathrm{NaOH}$ were added. $\mathrm{T}_{4}$ was then measured in all samples by RIA.

\section{HORMONE TURNOVER STUDIES}

For studies of thyroxine turnover, 2-4-year-old Columbia and Columbia Suffolk sheep were obtained from a local source. Animals were maintained at an environmental temperature of 57 $85^{\circ} \mathrm{F}$, were fed baled alfalfa, and had free access to water. To study the distribution and metabolism of labeled iodothyronine given intravenously, uterotomies were performed under local anesthesia in nine ewes of 100-140 days of gestation; indwelling exteriorized carotid and jugular vein catheters were placed in the fetuses. Two hours later fetal blood was obtained for measurements of $\mathrm{pH}, \mathrm{pO}_{2}$, and $\mathrm{pCO}_{2}$, and if normal, $100-200 \mu \mathrm{Ci}\left[{ }^{125} \mathrm{I} \mathrm{T}_{4}\right.$ or $\left[{ }^{131}{ }^{1}\right] \mathrm{T}_{3}$ (specific activity $80-100 \mu \mathrm{Ci} / \mu \mathrm{g}$ (25) was injected via the jugular vein catheter. After $24 \mathrm{hr}$ the fetuses were delivered by caesarean section, weighed, and killed.

To study absorption of $\left[{ }^{125} \mathrm{I}\right] \mathrm{T}_{4}$ from amniotic fluid, a small abdominal incision was made under local anesthesia in four ewes, 95-140 days of gestation. The uterus was exposed, and 100-200 $\mu \mathrm{Ci}\left[{ }^{125} \mathrm{I}\right] \mathrm{T}_{4}$ were injected into the amniotic sac. In two instances, the fetuses were delivered by caesarean section after $24 \mathrm{hr}$ and in two instances after $48 \mathrm{hr}$.

To study absorption of $\left[{ }^{131} \mathrm{I}\right] \mathrm{T}_{3}$ from amniotic fluid, laparotomy was performed on four ewes of 100-140 days of gestation. The uterus was exposed, the amniotic sac was identified, and 100-300 $\mu \mathrm{Ci}\left[{ }^{131} \mathrm{I}\right] \mathrm{T}_{4}$ were injected into the amniotic sac. All four fetuses were delivered by caesaréan section after $24 \mathrm{hr}$. The fetuses were weighed and killed as in the intravenous $\mathrm{T}_{4}$ experiments. The carcasses and organs of all fetuses were carefully dissected and weighed. Aliquots of the organs were weighed and homogenized and the homogenates counted with appropriate standards for ${ }^{125} \mathrm{I}$ radioactivity.

Serum samples from each fetus were extracted with butanol and alkali washed (10). The percentage of the injected dose of $\left[{ }^{125} \mathrm{IJT}_{4}\right.$ or $\left[{ }^{131} \mathrm{I}\right] \mathrm{T}_{3}$ remaining in the fetuses at death was calculated as the product of the serum concentration of butanol extractable ${ }^{125} \mathrm{I}$ or ${ }^{131} \mathrm{I}$ radioactivity and the $\mathrm{T}_{4}$ or $\mathrm{T}_{3}$ distribution volumes determined by kinetic methods in other fetuses (6). Descending chromatography of butanol-ammonia extracts of fetal sera were performed after $\left[{ }^{125} \mathrm{I}\right] \mathrm{T}_{4}$ injection using Whatman no. $3 \mathrm{MM}$

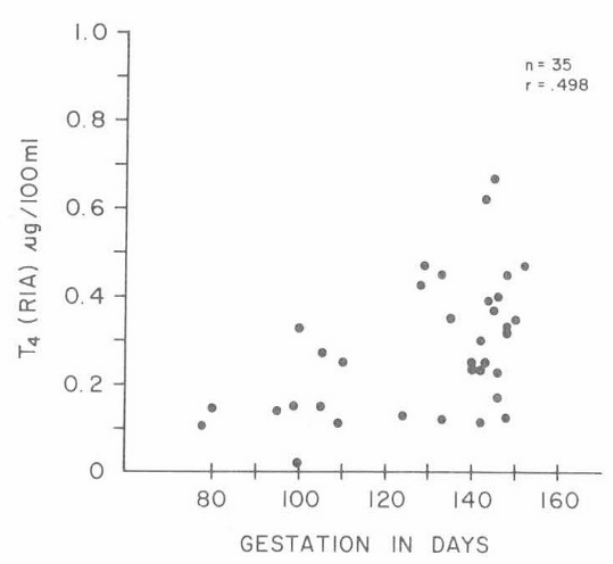

Fig. 1. Thyroxine $\left(T_{4}\right)$ concentration in micrograms per $100 \mathrm{ml}$ measured by radioimmunoassay $(R I A)$ in sheep amniotic fluid and plotted vs. gestational age in days. There is a progressive increase in $T_{4}$ concentration with age. $n=35$; correlation coefficient $(r)=0.498$.

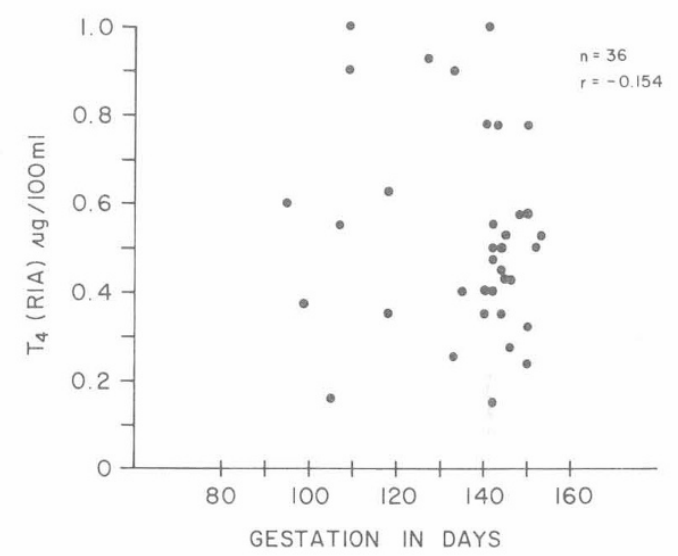

Fig. 2. Thyroxine $\left(T_{4}\right)$ concentration in micrograms per $100 \mathrm{ml}$ measured by radioimmunoassay $(R I A)$ in sheep allantoic fluid and plotted vs gestational age in days. The mean level is higher than in amniotic fluid and changes little with gestational age. $n=35$; correlation coefficient $(r)=$ 0.154 .

Table 1. Thyroxine $\left(T_{4}\right)$ concentrations in matched maternal and fetal sera and amniotic and allantoic fluids of sheep

\begin{tabular}{|c|c|c|c|c|c|}
\hline \multirow[b]{2}{*}{ Sheep } & \multirow{2}{*}{$\begin{array}{l}\text { Gestational } \\
\text { age, days }\end{array}$} & \multicolumn{2}{|c|}{$\begin{array}{l}\text { Serum } \mathrm{T}_{4}, \\
\mu \mathrm{g} / 100 \mathrm{ml}\end{array}$} & \multicolumn{2}{|c|}{$\begin{array}{l}\text { Fluid } \mathrm{T}_{4} \\
\mu \mathrm{g} / 100 \mathrm{ml}\end{array}$} \\
\hline & & Maternal & Fetal & Amniotic & Allantoic \\
\hline 340 & 95 & 8.4 & & 0.14 & 0.60 \\
\hline 380 & 99 & 8.0 & 7.2 & & 0.38 \\
\hline 041 & 105 & 6.8 & 8.0 & 0.15 & 0.55 \\
\hline $141 a$ & 109 & 6.8 & 8.4 & & 1.00 \\
\hline $141 b$ & 109 & 6.8 & 10.0 & 0.12 & 0.90 \\
\hline $50 a$ & 127 & 6.8 & 10.0 & & 0.93 \\
\hline 339 & 133 & 5.2 & 11.2 & 0.45 & 0.90 \\
\hline 361 & 135 & 4.0 & 8.4 & 0.35 & 0.40 \\
\hline$Z 2$ & 140 & & 8.4 & 0.25 & 0.40 \\
\hline 24 & 142 & 8.4 & 6.4 & 0.30 & 0.50 \\
\hline 22 & 142 & 4.4 & 9.6 & 0.13 & 0.55 \\
\hline 83 & 143 & 4.8 & 11.2 & 0.23 & 0.78 \\
\hline 21 & 145 & 7.2 & 9.6 & 0.68 & 0.43 \\
\hline D15 & 146 & 2.5 & 8.0 & 0.40 & 0.28 \\
\hline 14 & 146 & 4.0 & 15.6 & 0.23 & 0.43 \\
\hline $12 a$ & 148 & 3.0 & 7.2 & 0.34 & 0.58 \\
\hline $13 b$ & 150 & 4.0 & 7.6 & 0.35 & 0.38 \\
\hline 17 & 152 & 5.6 & 9.6 & 0.48 & 0.50 \\
\hline Mean & & 5.7 & 9.2 & 0.31 & 0.58 \\
\hline SEM & & 0.45 & 0.52 & 0.04 & 0.05 \\
\hline
\end{tabular}

paper using an $n$-butanol-acetic acid-water (12:3:5) solvent system, as described by Schultz et al. (21). A standard strip spotted with $\left[{ }^{125} \mathrm{I}\right] \mathrm{T}_{4}$ was run simultaneously in each system. After the chromatographs were developed the strips were scanned using a Nuclear Chicago Actigraph III.

\section{RESULTS}

$\mathrm{T}_{3}$ was unmeasurable in both amniotic and allantoic fluids throughout gestation. The sensitivity of the $T_{3}$ RIA system was 15 $\mathrm{ng} / 100 \mathrm{ml} . \mathrm{T}_{3}$ also was unmeasurable in most fetal sera as reported earlier (6). Maternal serum $\mathrm{T}_{3}$ concentrations were similar to values reported earlier (6) and are not shown.

The thyroxine concentrations determined by direct RIA of 35 amniotic fluid samples are plotted vs. gestational age in Figure 1. Values were low before 120 days of gestation; the mean \pm SEM of 10 samples between 74 and 110 days was $0.17 \pm 0.03 \mu \mathrm{g} / 100 \mathrm{ml}$. 
Table 2. Thyroxine $\left(T_{4}\right)$ and free thyroxine $\left(F T_{4}\right)$ concentrations in matched samples of fetal and maternal sera and amniotic and allantoic fluids

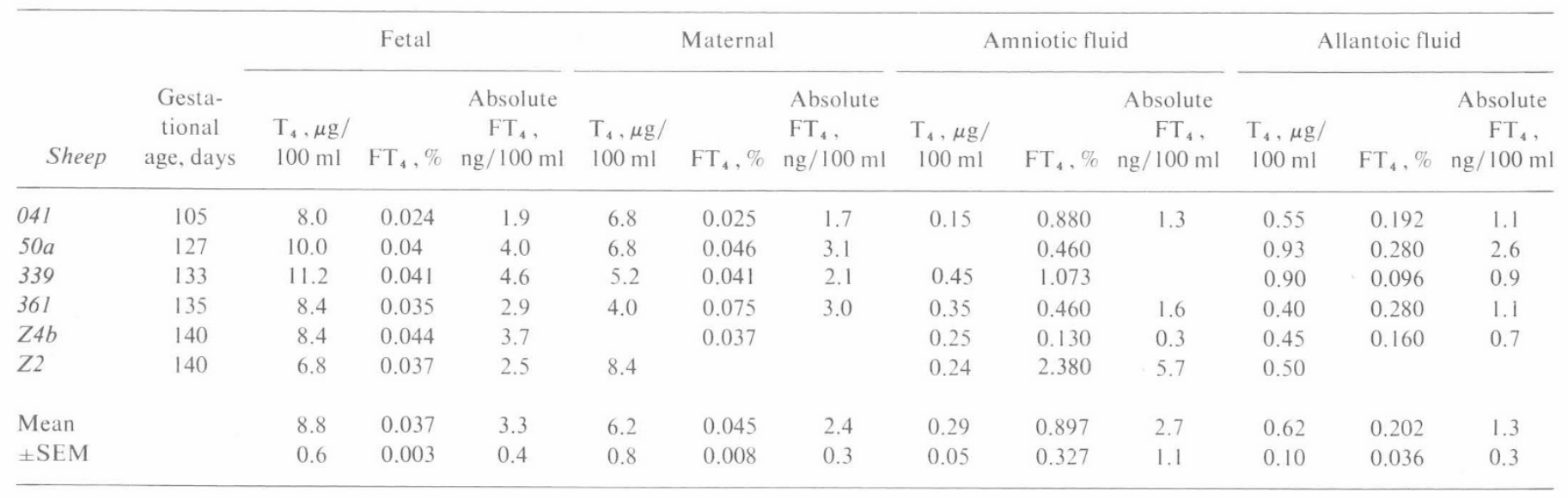

There was a progressive increase in concentration with gestational age so that between 124 and 152 days the mean of 25 samples was $0.33 \pm 0.03 \mu \mathrm{g} / 100 \mathrm{ml}$. There was a direct and significant correlation between gestational age and $\mathrm{T}_{4}$ concentrations in amniotic fluid $(r=0.498, P<0.005)$.

$\mathrm{T}_{4}$ values in allantoic fluid are shown in Figure 2. $\mathrm{T}_{4}$ concentrations were relatively high between 95 and 118 days $(0.57 \pm 0.1$ $\mu \mathrm{g} / 100 \mathrm{ml}, n=8$ ) and there was no increase in the mean $\mathrm{T}_{4}$ concentration with the progression of pregnancy. Also there was no correlation between allantoic fluid $\mathrm{T}_{4}$ concentration and gestational age $(r=0.154 ; n=36)$ or between amniotic fluid $\mathrm{T}_{4}$ and allantoic fluid $\mathrm{T}_{4}$ concentrations $(r=0.113 ; n=17)$. These results suggest that there is little free exchange of thyroxine between these two fluids during pregnancy.

Table 1 summarizes the $T_{4}$ concentrations from 18 pregnancies in which matched maternal and/or fetal sera and amniotic and/or allantoic fluid samples were available at different gestational ages. The mean $( \pm \mathrm{SEM}) \mathrm{T}_{4}$ concentrations in maternal and fetal sera were $5.7 \pm 0.45$ and $9.2 \pm 0.52 \mu \mathrm{g} / 100 \mathrm{ml}$, respectively. Values in amniotic and allantoic fluids were $0.31 \pm 0.04$ and $0.58 \pm 0.05$ $\mu \mathrm{g} / 100 \mathrm{ml}$, respectively. The mean $\mathrm{T}_{4}$ concentration was significantly higher in fetal than in maternal serum $(P<0.001)$, and the mean $\mathrm{T}_{4}$ concentration in allantoic fluid was significantly higher than in paired amniotic fluid samples $(P<0.001)$. There were no significant correlations between fetal serum $\mathrm{T}_{4}$ and amniotic fluid $\mathrm{T}_{4}$ concentrations $(r=0.090)$; between maternal serum $\mathrm{T}_{4}$ and amniotic $\mathrm{T}_{4}$ levels $(r=-0.117)$; between fetal serum $\mathrm{T}_{4}$ and allantoic fluid $\mathrm{T}_{4}$ concentrations $(r=0.229)$; or between maternal serum $\mathrm{T}_{4}$ and allantoic fluid $\mathrm{T}_{4}$ levels $(r=0.282)$.

Table 2 shows the free $\mathrm{T}_{4}\left(\mathrm{FT}_{4}\right)$ concentrations in several pregnancies where matched serum and fluid samples were available. These animals varied in gestational age from 105 to 140 days. The mean (and SEM) absolute $\mathrm{FT}_{4}$ concentration was $3.3 \pm 0.4$ $\mathrm{ng} / 100 \mathrm{ml}$ in the fetal sera, $2.4 \pm 0.3 \mathrm{ng} / 100 \mathrm{ml}$ in the maternal sera, $2.7 \pm 1.1 \mathrm{ng} / 100 \mathrm{ml}$ in amniotic fluid, and $1.3 \pm 0.3 \mathrm{ng} / 100$ $\mathrm{ml}$ in allantoic fluid. The mean total $\mathrm{T}_{4}$ concentration in allantoic fluid was again greater than the total $\mathrm{T}_{4}$ concentration in amniotic fluid $(P=0.02)$, but the mean dialyzable $\mathrm{T}_{4}$ fraction tended to be higher in amniotic fluid. The mean $\mathrm{FT}_{4}$ concentrations differed significantly only in fetal serum and allantoic fluid $(P<0.001)$.

Thyroxine concentrations measured by RIA before and after acid hydrolysis of allantoic and amniotic fluid are shown in Figures 3 and 4 . There was an increase in $T_{4}$ concentration after hydrolysis in 6 of the 10 allantoic fluid specimens and in 7 of 10 amniotic fluid specimens (Fig. 3). The mean (and SEM) $\mathrm{T}_{4}$ concentration in the 10 allantoic fluid samples increased from $0.17 \pm 0.02$ to $0.25 \pm$ $0.04 \mu \mathrm{g} / 100 \mathrm{ml}(P<0.05)$. In the 10 amniotic fluid samples the $\mathrm{T}_{4}$ concentration increased from $0.11 \pm 0.03$ to $0.19 \pm 0.04 \mu \mathrm{g} / 100$ $\mathrm{ml}(P<0.001)$.

Data on the organ distribution of radioactivity $24 \mathrm{hr}$ after

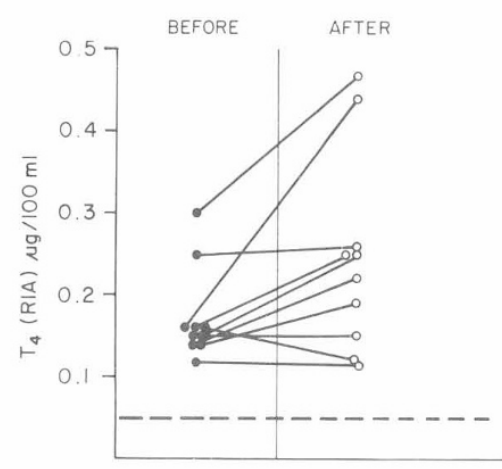

Fig. 3. Immunoreactive thyroxine in micrograms per $100 \mathrm{ml}$ in allantoic fluid of sheep before and after acid hydrolysis. The mean (and SEM) thyroxine $\left(T_{4}\right)$ concentration increased from $0.17 \pm 0.02$ to $0.25 \pm 0.04$ $\mu \mathrm{g} / 100 \mathrm{ml}$. RIA: radioimmunoassay.

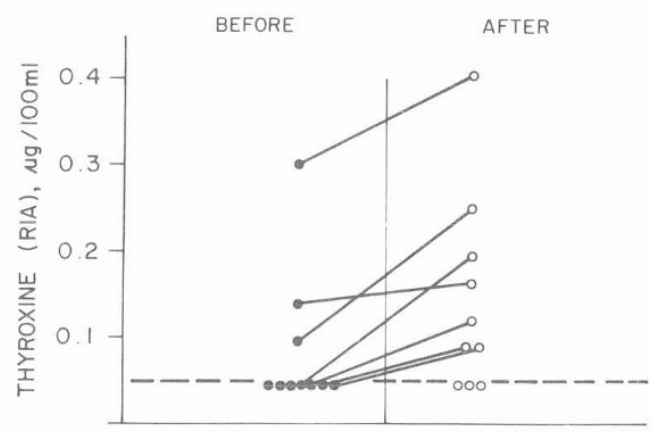

Fig. 4. Immunoreactive thyroxine in micrograms per $100 \mathrm{ml}$ in amniotic fluid of sheep before and after acid hydrolysis. The mean (and SEM) thyroxine concentration increased from $0.11 \pm 0.03$ to $0.19 \pm 0.04 \mu \mathrm{g} / 100$ $\mathrm{ml}$. RIA: radioimmunoassay.

intravenous injection of $\left[{ }^{125} \mathrm{I}_{\mathrm{T}} \mathrm{T}_{4}\right.$ and 24 and $48 \mathrm{hr}$ after intra-amniotic injection are shown in Table 3 . The mean radioactivity in the several organs or tissues was nearly identical whether the $\left[{ }^{125} \mathrm{I}\right] \mathrm{T}_{4}$ was injected intravenously or into amniotic fluid.

Table 4 shows the concentrations of $\left[{ }^{125} \mathrm{I}\right] \mathrm{T}_{4}$ and $\left[{ }^{125} \mathrm{I}\right] \mathrm{T}_{3}$ in plasma (percentage dose per liter) and the total residual labeled hormone in the fetal sheep (percentage dose per fetus) at the time of death. The mean $( \pm \mathrm{SEM})$ percentage of the administered $\mathrm{T}_{4}$ dose recovered $24 \mathrm{hr}$ after intravenous administration was $48.5 \pm$ $3.1 \%$; the mean value recovered after intraamniotic injection was $41.5 \%$ at $24 \mathrm{hr}$ and $27.7 \%$ at $48 \mathrm{hr}$. For injected $\left[{ }^{125} \mathrm{I}\right] \mathrm{T}_{3}$ the respective mean $( \pm$ SEM) percentages of administered doses recovered $24 \mathrm{hr}$ after intravenous or intra-amniotic fluid injection 
Table 3. Organ distribution of radioactivity in fetal sheep after intravenous (iv) or intraamniotic fluid (iaf) injection of ${ }^{125}$ I-labeled thyroxine $\left(\left[{ }^{125} I\right] T_{4}\right)^{1}$

\begin{tabular}{|c|c|c|c|c|c|c|c|}
\hline Sheep & Thyroid & Muscle & Liver & Lung & Kidney & $\begin{array}{l}\text { Cere- } \\
\text { bellum }\end{array}$ & Bowel \\
\hline \multicolumn{8}{|l|}{ iv fetuses } \\
\hline$K I$ & 0.3 & 8.2 & 1.9 & 1.0 & 0.6 & 0.3 & 1.5 \\
\hline$K 2$ & 2.6 & 7.9 & 1.9 & 1.2 & 0.5 & 0.7 & 1.4 \\
\hline K3 & 1.1 & 5.2 & 2.3 & 0.9 & 0.4 & 0.2 & 2.4 \\
\hline$K 4$ & 2.0 & 3.4 & 0.9 & 0.6 & 0.2 & 0.1 & 3.1 \\
\hline K5 & 3.0 & 4.8 & 1.8 & 1.4 & 0.4 & 0.3 & - \\
\hline Mean & 1.8 & 5.9 & 1.8 & 1.0 & 0.42 & 0.32 & 2.1 \\
\hline SEM & 0.5 & 0.9 & 0.2 & 0.14 & 0.07 & 0.10 & 0.4 \\
\hline \multicolumn{8}{|l|}{ iaf fetuses } \\
\hline \multicolumn{8}{|l|}{$48 \mathrm{hr}$} \\
\hline$L 2$ & 4.2 & 4.9 & 1.4 & 1.5 & 0.4 & 0.3 & 3.1 \\
\hline$L 3$ & 1.8 & 5.2 & 0.9 & 1.2 & 0.2 & 0.1 & 2.9 \\
\hline \multicolumn{8}{|l|}{$24 \mathrm{hr}$} \\
\hline L4 & 0.9 & 8.4 & 1.3 & 1.2 & 0.4 & 0.3 & 3.1 \\
\hline L6 & 1.3 & 6.1 & 1.7 & 1.3 & 0.4 & 0.2 & 4.2 \\
\hline Mean & 2.0 & 6.2 & 1.3 & 1.3 & 0.35 & 0.23 & 3.3 \\
\hline SEM & 0.7 & 0.8 & 0.2 & 0.7 & 0.05 & 0.05 & 0.3 \\
\hline
\end{tabular}

${ }^{1}$ Values are recorded as percentage dose per organ.

Table 4. Percentage of injected ${ }^{125} \mathrm{I}$-labeled thyroxine $\left(\left[^{125} I\right] T_{4}\right)$ or ${ }^{125}$ I-labeled triiodothvronine $\left(\left[{ }^{125} \mathrm{I}\right] T_{3}\right)$ in fetal sheep at killing after intravenous (iv) or intra-amniotic fluid (iaf) injection ${ }^{1}$

\begin{tabular}{|c|c|c|c|}
\hline & $\begin{array}{l}\% \text { dose } / \text { liter } \\
\text { plasma }\end{array}$ & $\begin{array}{c}\text { Estimated } \\
\text { distribution } \\
\text { volume, } \\
\text { liters }\end{array}$ & $\%$ dose $/$ fetus ${ }^{2}$ \\
\hline \multicolumn{4}{|l|}{$\begin{array}{l}\text { Thyroxine } \\
\text { iv fetuses }\end{array}$} \\
\hline $\begin{array}{c}24 \mathrm{hr} \\
(n=5) \\
\text { iaf fetuses }\end{array}$ & $39.8 \pm 10.2^{1}$ & $1.5 \pm 0.3$ & $48.5 \pm 3.1$ \\
\hline $\begin{array}{l}24 \mathrm{hr} \\
(n=2)\end{array}$ & $39(34 ; 44)$ & $1 ; 1.2$ & $41.5(40 ; 43)$ \\
\hline $\begin{array}{l}48 \mathrm{hr} \\
(n=2)\end{array}$ & $41(32 ; 50)$ & $0.5 ; 1.1$ & $27.2(21 ; 34)$ \\
\hline \multicolumn{4}{|c|}{$\begin{array}{l}\text { Triiodothyronine } \\
\text { iv fetuses }\end{array}$} \\
\hline $\begin{array}{c}24 \mathrm{hr} \\
(n=4) \\
\text { iaf fetuses }\end{array}$ & $3.31 \pm 1.07$ & $7.40 \pm 3.69$ & $19.7 \pm 2.5$ \\
\hline $\begin{array}{l}24 \mathrm{hr} \\
(n=4)\end{array}$ & $2.87 \pm 1.46$ & $5.80 \pm 0.95$ & $13.2 \pm 5.6$ \\
\hline
\end{tabular}

${ }^{1}$ Values are recorded as mean and SEM.

${ }^{2}$ Plasma concentration $\times$ distribution volume.

were $19.7 \pm 2.5 \%$ and $13.2 \pm 5.6 \%$. The mean percentage of the ${ }^{125} \mathrm{I}_{\mathrm{T}} \mathrm{T}_{4}$ dose in the fetal thyroid glands is shown in Table 3 for comparison with the percentage of butanol-extractable $\mathrm{T}_{4}$ radioactivity in the extrathyroidal pool. The thyroid ${ }^{125} \mathrm{I}$ content was similar whether the $\left[{ }^{125} \mathrm{I}\right] \mathrm{T}_{4}$ was given intravenously or injected into amniotic fluid; values ranged from 0.9 to $4.2 \%$.

The results of chromatography of the butanol-ammonia extracts of fetal sera are shown in Figure 5. Twenty-four hours after intra-amniotic injection of labeled $\mathrm{T}_{4}$ the serum radioactivity was predominantly $\mathrm{T}_{4}$. A significant iodide peak was observed as well as a small peak of radioactivity with an $R_{F}$ corresponding to that of $\mathrm{T}_{4}$ conjugate (Fig. 5). The $n$-butanol-acetic acid-water system does not separate $T_{4}$ and $T_{3}$ radioactivity. The pattern of fetal serum radioactivity was similar to the example shown in Figure 5 whether the $T_{4}$ was given intravenously or via amniotic fluid injection.

\section{DISCUSSION}

These results indicate that there are low but measurable concentrations of $\mathrm{T}_{4}$ in amniotic and allantoic fluids of the pregnant sheep. $\mathrm{T}_{4}$ is present as early as 95 days in allantoic fluid. The hormone might have been present even earlier if samples had been available for analysis. Nonetheless, significant quantities of $T_{4}$ are present in sheep amniotic and allantoic fluid at least by the second trimester. Thereafter the $\mathrm{T}_{4}$ concentration in amniotic fluid increases progressively until term. This is not the case in allantoic fluid, perhaps because after 90 days of gestation fetal urine is diverted from allantoic fluid and is passed in progressively greater amounts into the amniotic fluid via the urethra (22).

The increase in $\mathrm{T}_{4}$ concentrations after acid hydrolysis in both allantoic and amniotic fluids suggests that about one-third to one-half of the $T_{4}$ is present as $T_{4}$ conjugate. In addition, most of the $T_{4}$ is nondialyzable and presumably protein bound.

The lack of correlation between paired amniotic and allantoic fluid $T_{4}$ concentrations suggests that there is little free exchange of thyroxine between these fluid compartments during gestation. That this is true for other substances is apparent from the difference in color and opacity of the two fluids. There is also no correlation between the concentration of arginine vasotocin in these two fluids (19).

The lack of correlation between $\mathrm{T}_{4}$ concentrations in sheep fetal and maternal sera and $\mathrm{T}_{4}$ concentrations in amniotic and allantoic fluids suggests that in euthyroid sheep the amniotic and allantoic $\mathrm{T}_{4}$ levels do not reflect the thyroid status of the fetus and/or the mother. Rather, both must be represented in some way. Thus, the present results suggest that amniocentesis and measurement of $T_{4}$ in amniotic fluid is not a useful approach to assessment of fetal thyroid status. However, further studies in hypothyroid and hyperthyroid animals will be necessary to confirm this conclusion.

Almost identical fetal organ distribution of radioactivity was
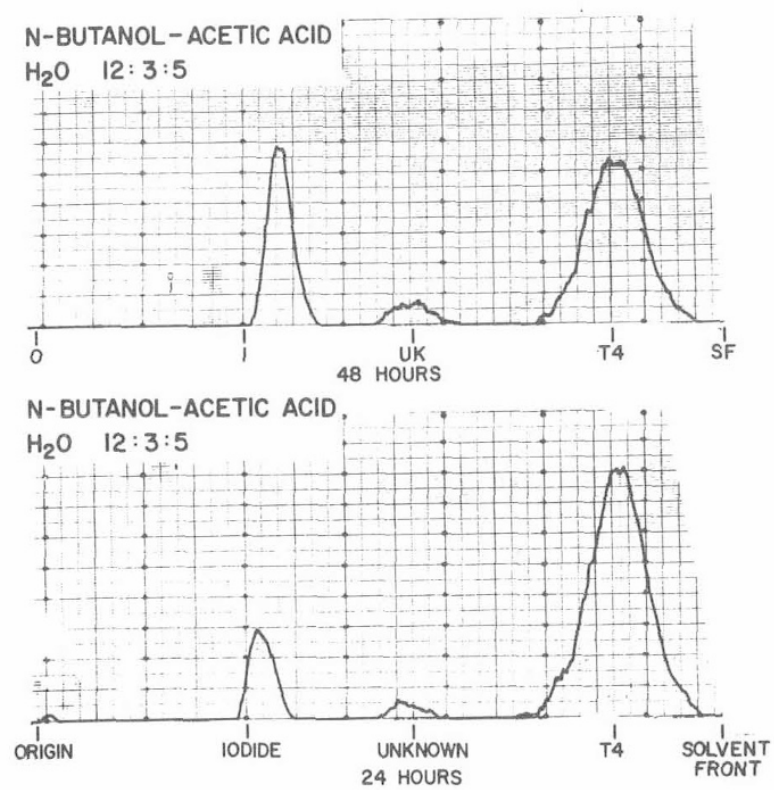

Fig. 5. Chromatograms of fetal sheep sera 24 and $48 \mathrm{hr}$ after intra-amniotic fluid injection of $\left[{ }^{125} \mathrm{I}\right]-\mathrm{T} 4$. The chromatograms were developed in a butanol-acetic acid- $\mathrm{H}_{2} \mathrm{O}$ (12:3:5) solvent system. The upper panel shows the 48-hr sample; the lower panel shows the $24-\mathrm{hr}$ sample. The small middle peak (unknown or $U K$ ) has an $\mathrm{R}_{F}$ corresponding to that of $\mathrm{T}_{4}$ conjugate. 
observed after $\left[{ }^{125} \mathrm{I}\right] \mathrm{T}_{4}$ was injected intravenously and into amniotic fluid. Also, the mean percentages of the administered dose of either $T_{4}$ or $T_{3}$ recovered in fetal sera after intravenous and after intra-amniotic injections were similar. Finally, the chromatographic patterns of fetal serum radioactivity were similar whether $\mathrm{T}_{4}$ was injected intravenously or into amniotic fluid. These results indicate that in the third trimester of pregnancy the sheep fetus absorbs $\mathrm{T}_{4}$ or $\mathrm{T}_{3}$ nearly quantitatively from amniotic fluid. The time of peak blood concentrations of $\mathrm{T}_{4}$ or $\mathrm{T}_{3}$ after amniotic fluid injection is not entirely clear; the similarity of $24-\mathrm{hr} \mathrm{T}_{4}$ values after intravenous and amniotic injections, the lower $\mathrm{T}_{4}$ concentrations $48 \mathrm{hr}$ after amniotic fluid injection, and the relatively low residual $\mathrm{T}_{3}$ radioactivity at $24 \mathrm{hr}$ suggest that absorption is essentially complete for either hormone by $24 \mathrm{hr}$. The results indicate that thyroid hormone can be administered to the fetus via amniotic fluid injection and suggest that this approach offers promise for the intrauterine therapy of fetuses in whom there is a high index of suspicion of hypothyroidism

\section{SUMMARY}

Amniotic and allantoic fluid samples were obtained by uterotomy from healthy pregnant ewes at various times during gestation; in most instances maternal and fetal blood were collected simultaneously. Serum $T_{4}$ free $T_{4}$, and $T_{3}$ were measured in the uterine fluid samples as well as material and fetal blood. $\mathrm{T}_{3}$ was immeasurable in uterine fluids as well as in most fetal sera. $\mathrm{T}_{4}$ concentrations were low in amniotic fluid early in gestation and increased progressively to term. The mean allantoic fluid $\mathrm{T}_{4}$ level was higher than the amniotic fluid concentration early in gestation and did not change with advancing gestational age. There were no correlations between uterine fluid and either maternal or fetal serum $T_{4}$ or free $\mathrm{T}_{4}$ concentrations at any time during gestation. Acid hydrolysis increased the immunoassayable $\mathrm{T}_{4}$ concentrations in uterine fluids, suggesting that a significant proportion of the hormone was present in conjugated form.

Fetal absorption of radioiodine-labeled $\mathrm{T}_{4}$ or $\mathrm{T}_{3}$ injected into amniotic fluid was assessed by measuring serum and tissue radioactivity 24 and $48 \mathrm{hr}$ after injection. Results were compared with levels of radioactivity measured $24 \mathrm{hr}$ after intravenous injection of the fetus. The mean $\mathrm{T}_{4}$ radioactivity in several organs or tissues, the total residual labeled $\mathrm{T}_{4}$ or $\mathrm{T}_{3}$ in the fetus at the time of death, and the patterns of serum $\mathrm{T}_{4}$ radioactivity after chromatography were similar after intra-amniotic and intravenous administration. These results indicate that $(I) \mathrm{T}_{4}$ levels in amniotic fluid do not reliably reflect fetal thyroid status, and (2) both $\mathrm{T}_{4}$ and $\mathrm{T}_{3}$ are rapidly and quantitatively absorbed from amniotic fluid by the sheep fetus.

\section{REFERENCES AND NOTES}

1. Abramovitch, D. R.: Fetal factors influencing the volume and composition of liquor amnii. J. Obstet. Gynecol., 77: 865 (1970).
2. Abuid, J., Stinson, D. A., and Larsen, P. R.: Serum triiodothyronine and thyroxine in the neonate and the acute increases in these hormones following delivery. J. Clin. Invest., 52: 1195 (1973).

3. Chopra, I. J.: A radioimmunoassay for measurement of thyroxine in unextracted serum. J. Clin. Endocrinol. Metab., 34: 938 (1973).

4. Dussault, J. H., Row, V. V., Lickrish, G., and Volpe, R.: Studies of serum triiodothyronine concentration in maternal and cord blood: transfer of triiodothyronine across the human placenta. J. Clin. Endocrinol. Metab. 29: 595 (1969).

5. Erenberg, A., Omori, K., Oh, W., and Fisher, D. A.: The effect of feta thyroidectomy on thyroid hormone metabolism in maternal and fetal sheep. Pediat. Res. 7: 870 (1973)

6. Fisher, D. A.. Dussault, J. H., Erenberg, A., and Lam, R. W.: Thyroxine and triiodothyronine metabolism in maternal and fetal sheep. Pediat. Res., 6: 894 (1972).

7. Fisher, D. A., Dussault, J. H., Hobel, C. J., and Lam, R. W.: Serum and thyroid gland triiodothyronine in the human fetus. J. Clin. Endocrinol. Metab., 36. 397 (1973).

8. Fisher, D. A., Hobel, C. J., Garza, R., and Pierce, C. A.: Thyroid function in the preterm fetus. Pediatrics, 46: 208 (1970).

9. Fisher, D. A. Lehman, H., and Lackey, C.: Placental transport of thyroxine. J. Clin. Endocrinol. Metab., 24: 393 (1964).

10. Fisher, D. A., Morris, M. D., Lehman, H., and Lackey. C.: Studies of butanol extractable iodine by the ceric oxidation method. Anal Biochem. 7:37 (1964).

11. Grumbach, M. M., and Werner, S. C.: Transfer of thyroid hormone across the human placenta at term. J. Clin. Endocrinol. Metab., 16: 1392 (1956).

12. Hopkins, P. S., and Thorburn, G. D.: The effects of foetal thyroidectomy on the development of the ovine foetus. J. Endocrinol., 49: 549 (1971).

13. Kearns, J. E., and Hutson, W.: Tagged isomers and analogues of thyroxine: Their transmission across the human placenta and other studies. J. Nucl. Med., 4: 543 (1963).

14. Larsen, P. R.: Direct immunoassay of triiodothyronine in human serum. J. Clin. Invest., 5l: 1939 (1972)

15. Leiblich, J. M., and Utiger, R. D.: Triiodothyronine in cord serum. J. Pediat., 82, 290 (1973).

16. Myant, N. B.: Passage of thyroxine and triiodothyronine from mother to fetus in pregnant women. Clin. Sci., 17: 75 (1958).

17. Pritchard, J. A.: Fetal swallowing and amniotic fluid volume. Obstet. Gynecol., 28: 606 (1966).

18. Raiti, S., Holzman, G. B., Scott, R. L., and Blizzard, R. M.: Evidence for placental transfer of triiodothyronine in human beings. New Engl. J. Med., 277: 456 (1967)

19. Sack, J., and Fisher, D. A.: Unpublished data.

20. Sack, J., Fisher, D. A., Hobel, C. J., and Lam, R. W.: Thyroxine in human amniotic fluid. J. Pediat., 87: 364 (1975).

21. Schultz, M. A., Forsander, J. B., Chez, R. A., and Hutchinson, D. L. The bi-directional placental transport of $\mathrm{I}^{131} 3: 5: 3^{\prime}$ triiodothyronine in the Rhesus monkey. Pediatrics, 35: 743 (1965).

22. Smith F. G., Adams, F. H., Borden, M., and Hilburn, J.: Studies of renal function in the intact fetal lamb. Amer. J. Obstet. Gynecol., 96: 240 (1966).

23. Sterling, K., and Brenner, M.: Free thyroxine in human serum: simplified measurement with the aid of magnesium precipitation. J. Clin. Invest., 45: 153 (1966).

24. Van Herle, A. J., Young, R. T., Fisher, D. A., Uller, R. P., and Brinkman, C. R., III: Intrauterine treatment of a hypothyroid fetus. J. Clin. Endocrinol. Metab., 40: 474 (1975)

25. Industrial Nuclear. St. Louis, Mo.

26. This research was supported by Public Health Service Grant HD-04270 from the National Institute of Child Health and Human Development. National Institutes of Health, Bethesda, Maryland.

27. Requests for reprints should be addressed to: D. A. Fisher, M.D., Division of Endocrinology, Harbor General Hospital, 1000 W. Carson St., Torrance, Calif. 90509 (USA).

28. Accepted for publication July 3, 1975. 